\title{
ENCONTROS E (RE)ENCONTROS COM IMAGENS DOCENTES: UMA ANÁLISE DISCURSIVA
}

\author{
ENCUENTROS Y (RE)ENCUENTROS CON IMÁGENES DOCENTES: UN ANÁLISIS DISCURSIVO \\ ENCOUNTERS AND (RE)ENCOUNTERS WITH TEACHERS' IMAGES: A DISCOURSE ANALYSIS
}

\author{
Maria Alzira Leite* \\ Universidade Vale do Rio Verde - UninCor - Três Corações - MG
}

\begin{abstract}
RESUMO: Este artigo objetiva analisar as representações sociais acionadas por um grupo de educadores sobre o ser docente. A premissa que orienta este estudo é a de que as nossas crenças e os nossos valores são consolidados nas práticas das quais participamos. Então, apresenta-se algo e atualiza-se esse representar, de acordo com a nossa história de vida, com as nossas experiências individuais, por meio das interações. Para este estudo, foram gravadas respostas de entrevistas, as quais foram analisadas com vistas a flagrar os movimentos das representações. A direção que se propõe para este estudo visa, principalmente, a uma análise de caráter linguístico-textual-discursivo, cujas bases epistemológicas perpassam abordagens de Foucault (1986), Pechêux (1988), Authier-Revuz (1995) e Bronckart (1999). De natureza explicativa e interpretativa, abordagem qualitativa, esta investigação nos fez perceber como os discursos podem revelar representações, pautadas nas ações coletivas e individuais, constitutivas do processo de construção da figura do profissional do ensino. Os exemplos discutidos revelam que os modos de enunciar dos educadores projetam imagens e sentidos ancorados numa memória discursiva, e estes se refletem em modelos elaborados e partilhados de professores, hoje, ressignificando os papéis, os posicionamentos e as representações com relação ao ser e ao fazer docente.
\end{abstract}

PALAVRAS-CHAVE: discursos; professores; representações.

RESUMEN: Este artículo tiene por objetivo analizar las representaciones sociales accionadas por un grupo de educadores sobre el ser docente. La premisa que orienta este estudio es la de que nuestras creencias y nuestros valores se consolidan en las prácticas en las que participamos. Así, se presenta algo y se actualiza ese representar, según con nuestra historia de vida, con nuestras experiencias individuales, a través de las interacciones. Para este estudio, se grabaron respuestas de entrevistas que fueron analizadas con el objetivo de capturar los movimientos de las representaciones. La dirección que se propone para este estudio pretende, sobre todo, un análisis de carácter lingüístico-textual-discursivo, cuyas bases epistemológicas se centran en abordajes de Foucault (1986), Pêcheux (1988), Authier-Revuz (1995) y Bronckart (1999). De naturaleza explicativa e interpretativa, abordaje cualitativo, esta investigación nos hace percibir cómo los discursos pueden revelar representaciones, basadas en acciones colectivas e individuales, constitutivas del proceso de construcción de la figura del profesional de la enseñanza. Los ejemplos discutidos revelan que los modos de enunciar de los educadores proyectan imágenes y sentidos anclados en una memoria discursiva, y estos se reflejan en modelos elaborados y compartidos de profesores, hoy, resignificando los roles, los posicionamientos y las representaciones en relación al ser y a al hacer docente.

PALABRAS CLAVE: discursos; profesores; representaciones.

ABSTRACT: This article aims to analyse the social representations made by a group of educators about being a teacher. The premise which guides this study is that our beliefs and values are consolidated in the discursive practices we take part in. Therefore, these representations are presented and updated according to our life stories and individual experiences through interaction. Responses from interviews were recorded for this study, which were then analysed in order to capture the movements of these representations. The direction proposed for this study aims mainly at a linguistic-textual-discursive analysis, whose epistemological bases underlie approaches by Foucault (1986), Pêcheux (1988), Authier-Revuz (1995) and Bronckart (1999).. Of an explanatory and interpretative nature and with a qualitative approach, this investigation helps us to realise how discourse may reveal representations, guided by collective, individual, and constitutive actions in the construction process of a teaching professional's image. The examples discussed reveal that the forms that the educators express themselves and project images and meanings are anchored in a discursive memory and these are reflected in models prepared and shared by teachers, who are currently giving a new meaning to their roles, positions and representations in relation to being a teacher and teaching.

KEYWORDS: discourse; teachers; representations.

\footnotetext{
* Doutora em Linguística e Língua Portuguesa pela PUC MINAS e professora do Mestrado em Letras na UninCor. Email: $<$ mariaalzira35@gmail.com>.
} 


\section{INTRODUÇÃO}

A discussão proposta neste artigo integra-se às minhas ações de investigação na PUC Minas, as quais, desde 2009, no âmbito de pesquisas de iniciação científica, mestrado e doutorado, venho me dedicando. Tais ações focalizam os estudos das práticas de letramento, do processo de formação de professores e das representações que perpassam o ser/fazer docente.

Logo, seguindo essa linha investigativa, numa tentativa de compreender fatores que concorrem para as representações do professor apresentadas/construídas nos seus modos de dizer, a reflexão que aqui apresento vem sendo tecida no campo de estudos que privilegiam a análise da materialidade linguísticotextual de discursos produzidos sobre o professor e sua práxis, em situação de entrevista.

Ressalto que, por um lado, discorrer sobre o professor é complexo, pois desafia o entendimento acerca da imagem e, ainda, do fazer docente. E, por outro, estudar os discursos que envolvem o ser docente é instigante, pois permite uma reflexão sobre outro objeto aliado a esse profissional que é o seu trabalho. Pensar nos discursos que perpassam o trabalho dos professores implica considerar como eles são vistos e se veem, o que de certa forma nos convida a levar em consideração o trabalho do professor como construção social, reflexo das mudanças sociais, que acarretam diferentes maneiras de organização do trabalho e, também, os novos olhares sobre as suas ocupações e acerca deles mesmos.

Convém destacar que a direção proposta para este estudo visa, especialmente, a uma análise de caráter linguístico-textual-discursivo, cujas bases epistemológicas perpassam, principalmente, as abordagens de Foucault (1986); Pechêux (1988); Authier-Revuz (1995) e Bronckart (1999), pautada em categorias dos modos de enunciar, para o exame do movimento da(re)construção da(s) representações sociais sobre o professor, o que, segundo o ponto de vista deste trabalho, pode afetar a forma de esse sujeito conceber a si mesmo e a sua relação com o mundo.

Nessa linha, o primeiro objetivo deste artigo é verificar como as representações sociais flagradas nos discursos podem (re)definir figura(s) docentes. Secundariamente, espera-se que este estudo possa também contribuir para pesquisas que se dediquem ao exame de mecanismos e estratégias enunciativas que põem em cena representações em atividades de interação nas esferas formativa ou profissional no âmbito educacional.

Saliento que esta seção em curso tem como finalidade apresentar a justificativa para a escolha do objeto de estudo, bem como os objetivos a serem alcançados. Na segunda, há uma exposição acerca do fenômeno do ato de representar, bem como da própria teoria das representações sociais e, ainda, os possíveis diálogos com a análise do discurso. Na terceira, exponho o percurso metodológico e, na quarta, as discussões dos resultados obtidos. Nas considerações finais, apresento a avaliação geral das análises da pesquisa empreendida, deixando algumas considerações sobre as contribuições da linguística para o mapeamento das representações sociais.

\section{REPRESENTAR NOS CAMINHOS DISCURSIVOS}

Como professora e pesquisadora, observo que os educadores vivem situações ligadas a uma educação contemporânea, que demandam mudanças rápidas; situações que os pressionam a lidar, por exemplo, com as novas tecnologias; com um novo perfil de aluno; e, também, de escola. Sendo assim, diante de uma realidade que não se conhece, instaura-se o desequilíbrio de esquemas já cristalizados, ancorados em concepções de uma linha tradicional de ensino. Com isso, deparamo-nos, por exemplo, com a insatisfação, com a fragilidade emocional dos professores e, muitas vezes, com a fuga das salas de aula e dos cursos de licenciatura.

O espaço do "não" é muito recorrente nos discursos dos professores. E, assim, ele tende a ser intensificado, principalmente, diante do novo, em que há uma pressão ${ }^{1}$ para que o educador mude; o que envolve o repensar as práticas que transformam o profissional, o seu grupo e a sociedade.

\footnotetext{
${ }^{1}$ A pressão para que os profissionais executem mudanças gerenciais e pedagógicas emerge face à realidade socioeconômica das sociedades modernas e avançadas.
} 
Lidar com o novo significa:

[...] descortinar o horizonte de incertezas no qual estamos envoltos representa, sem dúvida, um momento de desconforto, pois a inovação exige que nos desloquemos em modelos institucionais que há muito mostravam-se cristalizados. (ABREU, 2002, p. 2).

Cabe considerar que o novo sempre virá causando perturbações no estado de equilíbrio e, muitas vezes, a acomodação em que nos encontrávamos, mas isto não significa algo ruim; como diz Edgar Morin (2004, p. $30)$,

[...] o inesperado surpreende-nos. É que nos instalamos de maneira segura em nossas teorias e idéias, e estas não têm estrutura para acolher o novo. Entretanto, o novo brota sem parar. Não podemos jamais prever como se apresentará, mas deve-se esperar sua chegada, ou seja, esperar o inesperado.

Para tentar resolver um mal-estar, os sujeitos podem instaurar movimentos, que delineiam formas de representar, como sintetiza o esquema a seguir:
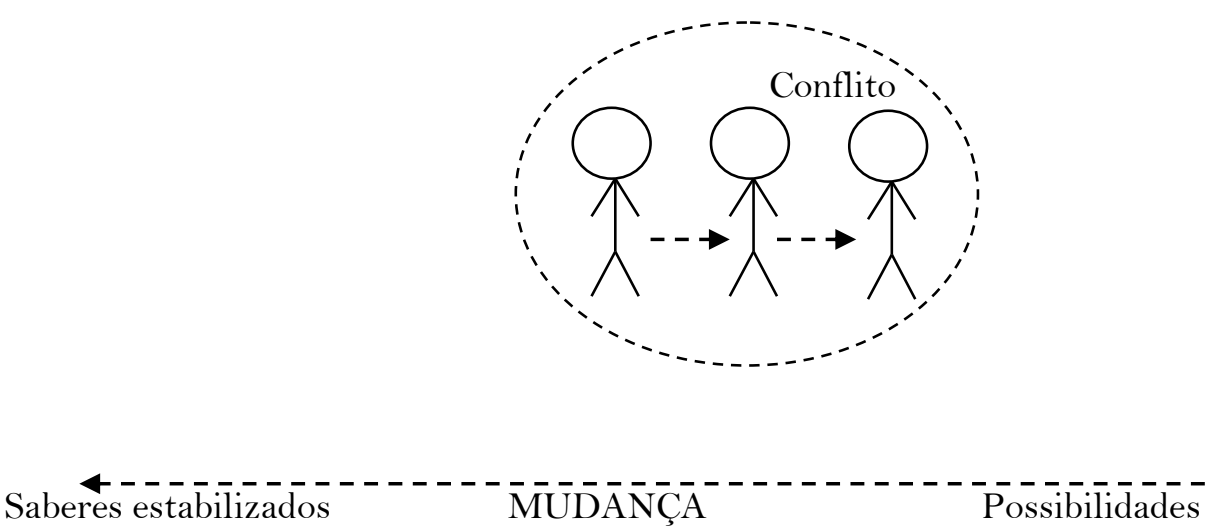

CONHECIMENTO EM MOVIMENTO

Esquema 1: Formas de representar

Fonte: Elaborado pela autora

Em um processo ligado aos conhecimentos de mundo, os sujeitos tentam inserir o novo objeto em seus saberes já estabilizados (MOSCOVICI, 2007). Ao vivenciar situações que pressionam para mudança, esses sujeitos podem:

- permanecer estáticos diante do que vivenciam;

(educadores que não alteram as suas formas de pensar, sentir e agir)

- alterar completamente seus saberes diante do conflito;

(educadores que alteram suas representações completamente; transformam-se)

- reelaborar os seus conhecimentos diante de um conflito.

(educadores que tentam se readaptar diante de um conflito)

Não há como falar em mudança na Teoria das Representações Sociais sem mencionar os dois processos sociocognitivos: o não familiar e o familiar. Isto é: assimilar e acomodar o estranho. Para isso, Moscovici (2007) destaca, então, a ancoragem e a objetivação. A objetivação é a passagem de conceitos e ideias para esquemas ou imagens concretas, transforma-se em "supostos reflexos do real" (MOSCOVICI, 2007, p.61). Ao objetivar, atribui-se um sentido a um signo que traduz os conhecimentos relativos ao objeto 
representado. A ancoragem diz respeito ao enraizamento social da representação, isto é, um pensamento constituído, cristalizado (MOSCOVICI, 2007). "Ancorar ideias estranhas é reduzi-las a categorias e imagens comuns." (ROCHA, 2012, p. 26).

Convém destacar que, ao pensar nas principais concepções sobre representações sociais, na perspectiva da Sociologia e da Teoria das Representações Sociais, percebo que nelas perpassam noções como ideias (SIMMEL, 1998), saber comum (WEBER, 1985), prática social (MARX, 1991), meio social (DURKHEIM, 1974), interação (MOSCOVICI, 1961), o que envolve linguagem e pensamento. Refletir sobre os processos significativos é resgatar, também, o trinômio signo-significação-representação. John Locke (1960), por exemplo, utilizou o termo "Semeiotiké" para designar uma "doutrina dos signos" e considerava signo e representação como conceitos sinônimos. Cabe, ainda, lembrar Pierce, que caracterizou a semiótica como a “teoria geral das representações” (SANTAELLA; NOTH, 1999, p. 16).

Assim, a representação exprime uma relação com um determinado objeto e esse ato de materializar algo envolve o conceito, a imagem, a ideia e o conhecimento. Não há como negar que a atividade representativa parte de um "estoque de saberes e experiências" (MOSCOVICI, 2012, p. 57) e, ainda, engloba a compreensão social e cultural da realidade por meio da representação. Nessa perspectiva, o real é visto como o sentido; recebe o sentido, enfim, é representado (CHARTIER, 1991).

Imbricando nesse ato de representar o real, temos o dizer: um objeto é representado por um nome, e um fato é representado por uma proposição (WITTGENSTEIN, 1984). É claro que não se trata, aqui, de considerar apenas as palavras cujos referentes se encontram no mundo, pois a linguagem envolve dimensões afetivas, orienta posicionamentos, prevendo modos de significar, de construção de sentido(s).

Como se pode notar, o conceito de representação social perpassa por diferentes concepções. Com efeito, a noção de representação atravessa as ciências humanas e não tem um lugar específico. Pode-se pensar em suas bases na sociologia, caminhando pela antropologia e na história das mentalidades. Nessa esteira, convém explicitar o lugar, aqui, de onde se fala, para situar o leitor da perspectiva teórica privilegiada pelo pesquisador. Acredita-se que a representação está envolvida nas práticas de linguagem e se projeta nos discursos, por isso a escolha por um estudo no qual se busca evidenciar o que o "discurso oculta ou pretende mascarar" (MAINGUENEAU apud GROSSMANN; BOCH, 2006, p. 16).

Mobiliza-se, então, aqui, a abordagem da Análise do Discurso Francesa, a qual, segundo Ferreira (1998), entende o discurso como um processo de significação que leva em conta a materialidade histórica da linguagem e o sujeito interpelado pela ideologia; isso está de acordo com os postulados de Pêcheux (1988), um dos fundadores da Análise do Discurso, que percebe as alocuções como "efeitos de sentido entre interlocutores" e o sujeito como dividido pela ideologia e o inconsciente, muito embora o sujeito esqueça-se de que é atravessado por duas ilusões e acredita ser fonte de suas palavras. Nessa linha, a Análise do Discurso concebe o sentido como passível de ser outro, determinado sócio-historicamente, marcado pela luta de classes e, portanto, sem vínculo com uma significação literal, como prevê a Análise de Conteúdo. Assim, para a Análise do Discurso, não existe um sentido literal, já que o literal é apenas um efeito discursivo, pois todos os sentidos são possíveis embora apenas o dominante se institucionalize como produto da história (ORLANDI, 2003), embora os sentidos estejam sempre em movimento e constantemente são recolocados no jogo do discurso.

Reitera-se, então, que é de uma perspectiva linguístico-discursiva que parte esta exposição, levando-se em consideração a linguagem como uma prática social, aproximando-se dos estudos de Moscovici (2007) e Marková (2006), quando estes exploram a relação entre as representações sociais e a linguagem. E assim, alinha-se a esta última, mais especificamente, quando enfatiza, que:

[...] é a constituição dessa linguagem específica que acompanha a formação de uma representação. Uma vez conseguido isso, as palavras obtêm seus sentidos específicos e esses, por sua vez, justificam seu uso na propaganda. A repetição dos elementos formaliza e solidifica o pensamento, tornando-o parte da constituição linguística e cognitiva do indivíduo. (MARKOVÁ, 2006, p. 341).

Nessa abordagem, pensa-se nas representações socialmente construídas pelas/nas interações, sustentando o caráter histórico, cultural e social das atividades humanas e dos signos linguísticos, por isso a importância da linguagem (BRONCKART, 1999). 
Num viés discursivo, as representações se movimentam reconstruindo-se nos discursos sociais que "testemunham, alguns, sobre o saber de conhecimento sobre o mundo, outros, sobre um saber de crenças que encerram sistemas de valores dos quais os indivíduos se adotam para julgar essa realidade" (CHARAUDEAU; MAINGUENEAU, 2004, p. 433). Esses discursos sociais emergem, às vezes, explicitamente, numa construção imagética, como, por exemplo, a imagem de um professor, ou, ainda, de maneira implícita, fazendo referência a um determinado discurso, no qual perpassa a figura docente.

\section{CAMINHOS METOdológicos}

Este artigo compõe uma investigação maior de doutorado, cujas análises contemplam os discursos que perpassam a profissão docente.

Para participar da pesquisa, selecionei sujeitos que: i) atuassem no Ensino Fundamental; ii) tivessem uma relação com o objeto de estudo; iii) possuíssem informações sobre a imagem docente e o seu fazer. Isso quer dizer que esses sujeitos não poderiam ter uma opinião calcada no achar, mas era preciso, também, possuir uma "experiência social" acerca do objeto de estudo (VALA, 2007).

Sobre isso, Moliner (1996) destaca que, embora os sujeitos se vejam cotidianamente diante de objetos que lhe são desconhecidos, isso não quer dizer que todos sejam geradores do fenômeno representacional. A representação é produzida coletivamente, ou seja, por um grupo, mas não qualquer grupo. Para o estudo das representações sociais, a concepção de grupo não se limita a um conjunto de indivíduos unidos pela interdependência ou por objetivos comuns, mas refere-se a um conjunto de indivíduos que mantém determinada relação com o objeto de representação, seja porque ele é parte de sua existência, seja porque não tem como ignorá-lo.

Esclareço que não considerei relevante para esta pesquisa selecionar os sujeitos pela rede de ensino na qual trabalhavam, por os participantes professores possuírem experiência tanto em instituições privadas quanto públicas. Sendo assim, escolhi aqueles que tanto faziam parte de escolas pública ou privada. Além disso, não pretendo ratificar, aqui, as imagens construídas, às vezes, estereotipadas, de um professor de escola pública e/ou particular.

Saliento, ainda, que não pretendo ter amostras de um universo, mas de pessoas que possuam conhecimento do objeto de estudo e, ainda, quisessem (re)pensar a(s) identidade(s) docente(s).

Como meio de coleta de dados, utilizei a entrevista semiestruturada focalizada, gravada em áudio. Optei por esse tipo de método, pois o mesmo permite a utilização de um roteiro de perguntas que pode ser adaptado de acordo com a necessidade do entrevistador, ou seja, se necessário, o pesquisador pode modificar a sua estrutura no momento das perguntas.

\section{OLHARES PARA AS REPRESENTAÇÕES}

Para se pensar as representações sociais, fez-se necessário um percurso na memória e no presente de experiências vividas por esses sujeitos, para tentar entender o movimento dessas representações hoje.

De acordo com o objetivo da pesquisa, seis questões foram propostas: a) com relação à imagem docente, quais são as suas memórias mais marcantes na sua história de aluno(a)? Enquanto estudante, algum professor lhe marcou positivamente ou negativamente? Como? Descreva. b) Para você, qual(is) a(s) principal(is) característica(s) que o professor deve possuir? c) Para você, qual seria a maior dificuldade, hoje, na profissão de professor? d) Como a sociedade, hoje, encara o professor? e) É fato que, hoje, o número de pessoas que se interessam por ser professor é pequeno. Por que você acha que isso acontece? f) Se você tivesse que dirigir uma mensagem a um jovem que quisesse seguir a carreira de professor, que mensagem você daria a ele? Para este artigo, selecionei quatro respostas de professores de língua portuguesa, atuantes no Ensino Fundamental, relativas à questão "f": Se você tivesse que dirigir uma mensagem a um jovem que quisesse seguir a carreira de professor, que mensagem você daria a ele?

Cabe pontuar que optei pela escolha de apenas uma questão para compor a pesquisa. A justificativa dessa escolha se deve em função da emoção, da dimensão afetiva que emergiu com maior intensidade, no momento 
do ato de reflexão para a composição da resposta. O espanto, o silêncio e o embargo da voz convergiam para uma autorreflexão dos próprios dizeres. Havia indícios de uma quebra de expectativa com relação às perguntas anteriores, ou melhor, a interrupção de uma sequência de repostas, gerando o flashback. Isso foi muito significativo, pois a emoção é o prelúdio da representação (WALLON, 2005). E, na interação com o meio, com o individual e com o social, pode-se criar e responder, reajustar e transformar as nossas representações.

Com relação à análise dos dados, segui um viés que levou em consideração a interpretação que perpassa cada etapa do estudo - a observação, a entrevista, os discursos e, ainda, os resultados obtidos. Em outras palavras, a interpretação faz parte do caminho metodológico. Além disso, lidar com as representações dos sujeitos envolvidos na pesquisa, de certa forma, é trabalhar, também, com as nossas representações, o que envolve a "construção do/a pesquisador/a, que parte da sua própria cultura científica, e do conhecimento mais amplo da sociedade como um todo, que permite o ir e vir do seu olhar entre um grupo específico e o conjunto da sociedade.” (ARRUDA, 2005, p. 233). Nessa linha, a interpretação nos auxiliou a entender as etapas do estudo, o que os dados poderiam significar a partir do contexto produzido e do referencial teórico que nos orientou no problema a ser pesquisado.

De acordo com Arruda (2005, p. 233), a interpretação

[...] é um nervo da pesquisa; ela conecta os dados entre si e com o problema pesquisado e dá a eles um desenho integrado, mostrando como circula entre todos os achados a corrente da lógica que os anima, a sua relação e também a sua relação com o mundo.

Sendo assim, o trabalho interpretativo, além de ser o alicerce do pesquisador, em termos de lidar com a investigação, acompanha, também, o nosso percurso. Porém, como ressaltam Bauer, Gaskell e Allum (2000, p. 24), é necessário um cuidado com a interpretação, principalmente nas pesquisas qualitativas, pois "os dados não falam por si mesmos, mesmo que sejam processados cuidadosamente, com modelos estatísticos sofisticados", então tendemos a explicar, entender os dados, sem critérios.

Atente-se ainda para o fato de é preciso preparar o percurso no qual se dará a interpretação. E a partida está na aproximação com o objeto de estudo, isto é, além de conhecê-lo, verificar os contextos de suas representações. Segundo Flick (2001), são as chamadas condições de produção da representação, isto é, as vivências e as influências que incidem nessa produção, perpassando os valores adotados até a forma de comunicação na qual os pesquisadores estão expostos - a história/cultura, a vivência e a experiência.

Arruda (2005) orienta-nos a pensar numa contextualização em espiral, pautada em um movimento múltiplo. A espiral parte, pois, de

[...] contexto-espaço-temporal imediato para o mais distante, que pode ser o percurso das idéias a respeito daquele objeto, ou daquele grupo, e pode mesmo ir além, mas sem omitir a cultura que lhe é própria, com os seus modelos, valores, o saber local, e o imaginário social circulante. (ARRUDA, 2005, p. 235).

O esquema abaixo ilustra essa concepção. 


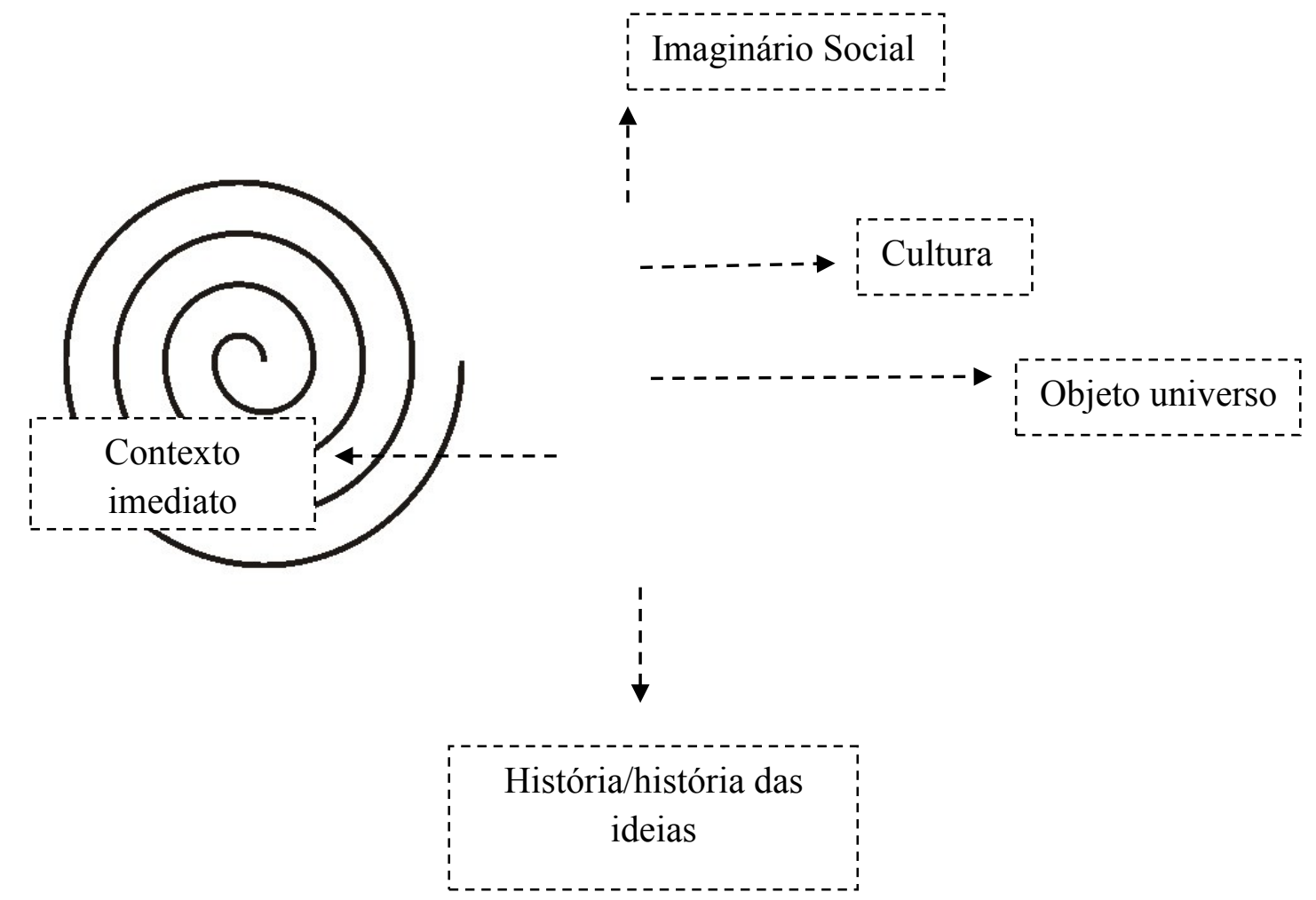

Esquema 2: Contextualização para interpretação

Fonte: Elaborado por Arruda (2005, p. 235)

De acordo com Arruda (2005, p. 236), para se verificarem as condições de produção das representações sociais, é necessário levar em consideração a fluidez do percurso das ideias. Assim, "o que importa é que a espiral tem uma direção que se irradia em torno da díade objeto-universo estudados, reafirmando uma vez mais que toda representação é representação de alguém e de alguma coisa [ [...]”.

Convém destacar que, além de considerar os aspectos ilustrados na espiral acima, insiro no esquema abaixo, fazendo uma adaptação da abordagem de Arruda (2005), uma análise que se paute nos discursos produzidos por sujeitos em diferentes situações de interação, nas diversas esferas. Nessa espiral, os discursos podem se imbricar, se atravessar, movimentando o percurso das ideias e (re)construindo representações. 

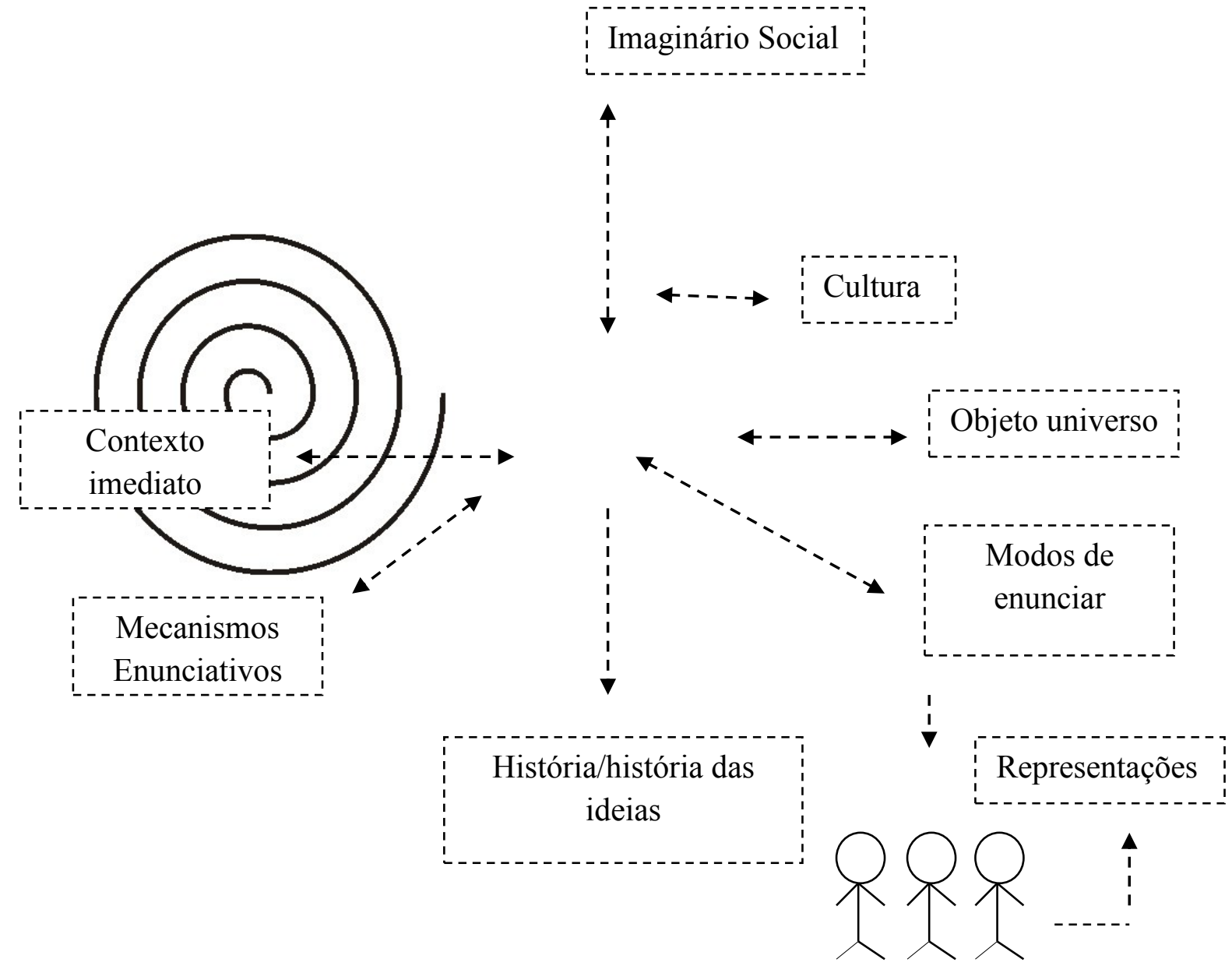

Esquema 3: Contextualização, interpretação e a interação

Fonte: Adaptado de Arruda (2005, p. 235)

Por isso, na análise dos dados, considero, além da interpretação e da contextualização, a interação entre os sujeitos para mapear representações projetadas nos modos de dizer. E, ainda, levo em conta o fato de os mecanismos enunciativos orientarem a produção de sentido.

Mas como fazer isso do ponto de vista linguístico? Considerando os mecanismos enunciativos, as manifestações de metadiscursividade, os recursos de construção de referentes. E, ainda, levando-se em conta as pistas das formações discursivas orientadoras dos discursos dos sujeitos. E quanto às modalizações, para explicitar as posições do enunciador frente ao interlocutor, levando em consideração o seu propósito comunicativo.

Considerar a interação significa observar como os discursos se alinham em termos de perguntas e respostas, de negociação de pontos de vista e, ainda, caminhando para um todo de coerência pragmática.

\section{5 (RE)SIGNIFICANDO AS IMAGENS ACERCA DO PROFESSOR}

Nos excertos apresentados, sinalizam-se as dimensões representacionais do ser professor e, ainda, a objetivação de um "eu", isto é, a construção de um sujeito aconselhador e educador, quando se deparam com a última questão provocadora. Nessa interação entre entrevistado e entrevistador, os discursos dependentes das condições de produção são ancorados no contexto imediato de produção, mas, também, numa memória discursiva.

Leia-se a primeira resposta trazida a esta seção: 


\section{Cena da entrevista 1}

(...) eu diria... que ele deve escolher a profissão de professor se... ele realmENte gostAR de tER convivência com as pessoas. Eu faria uma reflexÃO com essa pessoa... Do que você gosta? Por que você está pensando em SER professor? Eu não acredito que a pessoa vai escolher a profissÃ̃ por saudosismo ou por paixão, entende? (...) Eu diria que ele deve escolher a profissão de professor se ele realmente gostar de ter convivência com as pessoas.

Fonte: corpus coletado para esta pesquisa.

Veja-se que o enunciador recorre ao uso da condicional "se" e ao modalizador "realmente", elementos que acentuam o viés de advertência, como algo que precisa ser cumprido para ser professor. Seguindo essa linha, abre-se um espaço de reflexão, e o enunciador convida o interlocutor para também pensar sobre o assunto em pauta por meio de perguntas diretas. Note-se que há uma construção de uma representação de um profissional ponderado; aquele que detém um saber sobre a escolha da profissão docente, pois acredita numa opção profissional, fundamentando-se no perfil de um profissional que gosta "de ter convivência com as pessoas". Nessa linha, outros enunciadores são trazidos à cena para efeito de argumentação e fundamentação. Tem-se, assim, a emergência de vozes de um aconselhador, de um professor, participante de uma pesquisa, também pesquisador, e legitimando o papel, nessa cena, de aconselhador. E, nesse ponto, no papel de aconselhador, agencia, no valor semântico dos termos "se" e "escolha", o que é expresso e dito seja professor - e o não dito - orientado pela ação do verbo "diria" no futuro do pretérito e, ainda, por uma modalização epistêmica, marcada no termo "realmente", indicando um eixo de avaliação da condição de ser professor: siga outra profissão.

O discurso anterior nos faz retomar a heterogeneidade, cujo pressuposto atribui ao sujeito seu descentramento e, ao outro, um papel primordial no discurso do mesmo. (AUTHIER-REVUZ, 1990).

Para deixar clara essa abordagem, convém pontuar que, em Authier-Revuz (1990; 1998; 2004), a heterogeneidade é estabelecida a partir da noção de heterogeneidades enunciativas, apresentadas como: a constitutiva e a mostrada. A primeira refere-se "aos processos reais de constituição de um discurso"; a segunda, aos "processos de representação, num discurso, de sua constituição." (AUTHIER-REVUZ, 1990, p. 32). Nessa perspectiva de distinção, mas não de separação entre as heterogeneidades constitutiva e mostrada, Authier-Revuz (1990, p. 26) adota os casos de heterogeneidade mostrada como "formas linguísticas de representação de diferentes modos de negociação do sujeito falante com a heterogeneidade constitutiva do seu discurso", considerando a existência de dois tipos de enunciados: aqueles que mostram a heterogeneidade, com marcas explícitas, e aqueles cujas marcas não são mostradas. No caso deste estudo, fazemos menção à heterogeneidade mostrada e não marcada.

De qualquer maneira, as representações podem ser trazidas nos modos da presença do outro. Dialogicamente, no trabalho com o seu próprio dizer, o professor traz à tona a concepção de instâncias ligadas a um sistema tradicional, refutando-a, e marcando, então, a sua representação docente: "gostar de ter convivência com as pessoas". Nessa visão, subentende-se o professor interativo.

Convém destacar que, no momento em que o gravador foi desligado², o enunciador em foco indagou:

\section{Cena da entrevista 2}

Você já desligou o gravador? Olha, na realidade não é nada disso que eu queria dizer. Você sabe... Ser professor hoje é muito difícil. A indisciplina, os baixos salários, a desvalorização. Eu mesma já falei com a minha irmã que não vale a pena fazer licenciatura, quando ela demonstrou um interesse em fazer Letras. Não vale a pena ser professor, hoje!

Fonte: corpus coletado para esta pesquisa.

Numa autocorreção, metadiscursivamente, o enunciador se desenha, agora, como um profissional que vive os problemas atuais que cerceiam o trabalho docente: "indisciplina", "baixos salários", "desvalorização" da pessoa e do profissional. Utiliza, inclusive, uma experiência pessoal ao dissuadir a irmã no prosseguimento dos estudos buscando licenciatura com argumentos baseados na sua realidade. Nessa medida, conduz o

\footnotetext{
${ }^{2}$ Após desligar o gravador, a entrevista ainda permaneceu em tom informal, quando a entrevistada abre um discurso em tom de desabafo. Convém pontuar que, a entrevistadora solicitou permissão ao sujeito da pesquisa para transcrever aquele depoimento. Houve o consentimento. Após a transcrição, o texto foi lido para a entrevistada e a mesma autorizou o seu uso em pesquisas.

Forum linguistic., Florianópolis, v.11, n.4, p.415-428, out./dez.2014.
} 
interlocutor a perceber o lado negativo da profissão e projeta-se, assim, a representação do professor desvalorizado.

Cabe destacar que essas representações nos permitem refletir, inclusive, acerca dos novos significados do fazer docente. Esse sujeito assume-se como um trabalhador, que tem nas suas práticas de linguagem, a orientação do "ser professor" e a compreensão dos processos de letramento dos quais ele faz parte.

De acordo com Charaudeau (2006), o sujeito apresenta uma identidade social que funda a sua legitimidade de ser comunicante em decorrência do estatuto dos papéis que lhe são atribuídos pela situação comunicativa. No primeiro relato desse enunciador, há indícios de um querer dizer tendo em vista o pesquisador, a investigação e o próprio papel que o participante assume naquele evento, considerada, sobretudo, a questão que lhe foi proposta.

No segundo, considerando a situação de enunciação, o enunciador dirige-se ao entrevistador convidando-o para aderir ao seu posicionamento. Esse convite marcado pela escolha "você sabe" direciona o discurso a um interlocutor, no caso o entrevistador, a um grupo particular, que também pode compartilhar daquela representação. Observe que a escolha lexical "eu mesma" acentua e legitima o seu argumento de detentora de uma experiência de quem sabe o que fala. É claro que convém destacar que se constrói, aqui, uma identidade discursiva do enunciador, aconselhador, atrelado aos papéis atribuídos no ato de enunciação, decorrentes das coerções comunicativas que lhe são impostas e das estratégias discursivas que ele resolve seguir, por isso um discurso com o gravador ligado, e tudo que envolve essa cena, e outro, com o mesmo desligado. Charaudeau sustenta, então, que as identidades podem fusionar no ethos, visto que a distinção entre tais identidades - social e discursiva - é tênue, sobrepondo-se muitas vezes uma na outra.

No próximo fragmento de outra resposta, o riso do enunciador parece contemplado por um ar disfarçado de ironia, atitude que pode estar orientada para uma proteção de face, visto tratar-se de uma temática de seu trabalho diário, ou por considerar difícil aconselhar um jovem a seguir a profissão docente, levando-se em consideração a realidade precária que envolve algumas instituições de ensino e seus colaboradores.

\section{Cena da entrevista 3}

(risos) Ah, eu não sei... É um trabalho que requer muita dedicação, uma certa devoÇÃO, um esforço, um empenho... a mensagem é... se dedica ao MÁximo possível para ser um BOM professor, dar uma BOA aula e, também, se enCAre como professor... se identifique como professor, SEJA como um trabalhadOR que atue nessas condições preCÁrias!

Fonte: corpus coletado para esta pesquisa.

Em virtude das possibilidades, marcadas pelo "não sei” e pela força ilocucionária assertiva da expressão "é um trabalho que requer X", infere-se que o sujeito constrói sua resposta recorrendo ao tom de reflexão e posterior aconselhamento. As escolhas lexicais como "devoção", "esforço" e "empenho" orientam-nos para uma representação de trabalho docente ancorada numa memória discursiva ligada ao sacerdócio. As especificidades do ser professor para esse enunciador, aconselhador, são postas gradativamente, acentuando e assinalando o ideal positivo para o perfil docente: "se dedica ao máximo"; "dar uma boa aula". O enunciador se apropria de um discurso militante, de uma Pedagogia Libertária (GALLO, 1996), na qual se prioriza o discurso e a ação. Nessa linha, destaca mais uma especificidade, por meio do discurso imperativo pautado no "se encare"; "se identifique" como professor.

O não dito emerge numa voz que adverte:

- Existe trabalhador que não atua em determinadas "condições precárias".

E, também, o dito numa voz que incentiva.

- se encare como professor, se identifique como professor, seja como um trabalhador que atue nessas condições precárias.

O discurso imperativo é concluído pelo eco de um enunciado marcado pela ironia. Essa ironia é construída gradativamente nas ações verbais cujo alvo determinado é o futuro professor. Aqui, a autonomia e o sarcasmo se mesclam quando o enunciador como professor faz eco a si mesmo e no momento que se faz referência ao seu interlocutor. 
Na próxima mensagem, observe-se que o enunciador desenha o docente como aquele que se constrói como profissional tanto na academia, quanto na prática, concluindo esse processo de construção naquele que edifica o conhecimento: o professor.

\section{Cena da entrevista 4}

(risos) as coisas são muito complexas. Eu incentivaria, puxa, é LEGAL demais! Isso MESmo! Mas... eu acho que é preciso falar daquilo que é negativo. Eu acho que o problema é esse. Na escola só se aponta o que é negativo, sabe? Você chega na academia, só se aponta o que é posiTIvo. Só tem coisas boas... só tem coisas maravilhosas::: lá é o pará́so. Você chega dentro... em sala de aula... você vai ver as crianças... os adolescentes... lá... querendo aprender... você vai passar, ensinar a fazer análise sintática.... é a coisa mais LEGAL do mundo fazer análise sintática e NÃO é. É tediOSO! Você chega na escola, por exemplo, como estagiário, e só falam coisas negativas para você! E você não está formado ainda! As pessoas não têm um pingo de misericórdia de você! Não tem um pingo de misericórdia. Não mexe com isso não! Você que é o ingênuo que vem com essa visão romântica. Ihhh, vem você com o discurso da ACADEMIA! Você que é o inocENte! Você vem com esse discurso romantizado da academia, com essa visão idealizada do ensino. Meu FIlho, aqui... é OUtra realidade! E, você pensa, nossa, eu aprendi ISSO, na disciplina universitária... E, você fica nesse choque! Mas, eu incentivaria, porque precisa! Você precisa do professor como precisa do médico. Eu não vou falar, o professor é a melhor profissẽO do que as outras, porque....TODA profissão é digna. Se não tiver um pedreiro para construir a casa... meu amigo, o médico tem que sair de lá... para construir... alguém tem que fazer...TOda profissão é digna e tem que ser valorizada. E se essa pessoa quer ser professor, é um desejo dela, ela deve pensar qual é o meu papEL ALI? Eu quero fazer diferença na vida do OUtro? É isso.

Fonte: corpus coletado para esta pesquisa.

O riso antevê a resposta. Não se pode afirmar, contudo, se o riso desse enunciador denota ironia ou certo conforto/desconforto quando solicitado a construir a mensagem acerca do aconselhamento. O indício de um incômodo da pergunta se acentua quando o enunciador discorre sobre a complexidade "das coisas", isto é, o que cerceia o universo docente. Após segundos de introspecção, refaz-se para acenar positivamente no incentivo proposto: ser professor. Apesar de recorrer ao termo incentivar, esse enunciador se constrói muito mais na ação da advertência. Ao retroagir em seus pensamentos, como um professor em formação, apresenta-nos os dois polos que perpassam a formação docente: i) crítica à universidade, um lugar onde se preconizam os aspectos positivos que envolvem o ser docente; ii) julgamento das práticas de ensino no cotidiano da sala de aula.

A dicotomia de um discurso da universidade e de outro pautado na prática docente é legitimada no interdiscurso da equipe pedagógica ancorado numa ideia "romantizada da academia" e na "visão idealizada de ensino".

Pode-se observar que, no discurso indireto do professor em formação, não há somente o discurso de um jovem ingressante na carreira docente, mas, também, os posicionamentos de outras instâncias: universidade, escola e equipe pedagógica. Esse posicionamento está pautado num já-dito, imbricado em nós e nas estratégias discursivas, marcadas por uma orientação axiológica, nas quais os enunciadores se incluem. Essa dimensão axiológica apresenta discursos já-ditos.

- o professor em formação é inocente;

- o professor em formação possui uma ideia romântica da escola;

- a escola é outra realidade;

- o discurso da universidade é muito distante da prática escolar.

Diante disso, o incentivo fica à margem. Porém, é resgatado pelo enunciador quando representa essa profissão como honrada, acentuando-a como qualquer outra. Nesses termos, recorre à escolha de duas profissões para ilustrar o seu modo de configurar o docente. A primeira escolha, "pedreiro", acentua a dignidade. Subentende-se nesse termo uma metáfora ligada àquele que possui característica em torno do edificar o saber. A outra, ao médico, infere-se uma imagem ancorada ao ato de prestar assistência. 
A escolha desses termos, isto é, dessas profissões, considerada a ação de comparação realizada, revela que se opera com elementos que não estão no mesmo plano, tendo em vista o valor que estes recebem em nossa cultura. Na concepção desse enunciador, independente do status do profissional, o edificar e o cuidar se aproximam, em termos de ações dignas, porém, ele deixa transparecer em seu discurso, na comparação estabelecida, que o construir está na base metonímica do ensinar; desse modo, o professor estaria para o pedreiro, e não para o médico. Essa representação docente, próxima à imagem de pedreiro, está fundamentada na ação da construção de X, nesse caso, do conhecimento. Pode-se inferir, assim, que o professor é a base para outras profissões, como a do médico.

\section{CONSIDERAÇÕES FINAIS}

Iniciar uma pesquisa num viés linguístico e ter, como parte dela, o aporte teórico a Teoria das Representações Sociais, foi um desafio. Quando iniciei esta investigação, imaginei, a princípio, que o estudo fosse ser complexo, o que realmente se deu. Os conceitos, em torno das representações, soavam tão distantes daqueles que eu estudara que aproximá-los constituía e ainda constitui o meu grande desafio. No decorrer do caminho, notava que as dificuldades eram superadas na medida em que os diálogos entre as duas áreas começaram a ganhar corpo, fazendo sentido para mim e para os meus interlocutores.

Prosseguindo na tarefa investigativa, destaco o protagonista: o professor. Apesar de esta pesquisa não focar esse objeto, não há como desconsiderar a sua centralidade em termos de significância. Direcionado a ele, estão o(s) olhar(es) que apontam e falam. Interpretar essa visão instituiu o meu foco, nesses últimos anos. Uma visão arrolada nos discursos.

Pautando-me nos modos de enunciar de educadores, encontrei nos aportes teóricos e metodológicos da Análise do Discurso e das Teorias da Enunciação amparo para fortalecer a estrutura desta pesquisa. Para o estudo dos modos de dizer, optei pelos mecanismos enunciativos, as manifestações de metadiscursividade, os recursos de construção de referentes e, ainda, levando em conta as pistas das formações discursivas orientadoras dos discursos dos sujeitos. Quanto às modalizações, estas foram examinadas de modo a explicitar as posições do enunciador frente ao interlocutor, levando em consideração o seu propósito comunicativo. Tomando esse quadro, levei em consideração que o uso da linguagem possibilita aos indivíduos mecanismos para uma (re)construção simbólica da realidade, dando sentido aos fatos que os cerceiam (MARKOVÁ, 2006).

Os dados revelaram que, apesar de emergir no nosso cotidiano um discurso da instância cidadã que nega a escolha da profissão docente “por saudosismo ou por paixão”, existem representações ancoradas em especificidades do professor vinculadas ao “dom”, a “uma vocação”. Essas representações estão cristalizadas num viés tradicional do "seja como um trabalhador que atue nessas condições precárias”.

Isso não quer dizer que os professores vivam essa prática, apesar de discursivisá-la. Como existe uma pressão social para que possam alterar as suas formas de pensar, agir e sentir, os educadores tentam reelaborar as representações, às vezes, no espaço do “Não vale a pena ser professor, hoje!”. No processo de reconstrução de representações, a reelaboração, mais uma vez, se instaura, quando os educadores abrem espaço para reflexão, procurando respostas para o baixo lugar social da profissão.

No movimento dos processos representacionais, emergem figuras docentes ligadas a um perfil idealizado em termos de constituição, pautado numa imagem ainda que missionária; num viés interativo, voltado para a ação, e realizado, legitimando-se numa concretização. Nesse sentido, os educadores seguem uma ação de advertência, uma chamada de atenção para problemas que perpassam a profissão.

Os resultados nos orientam, ainda, a refletir acerca dos desafios que cerceiam a esfera educacional. Esses desafios influenciam as representações. O primeiro diz respeito à preparação do professor, ainda em formação, para a prática. O distanciamento desses dois discursos - acadêmico e da escola - dificulta a concretização do perfil desse profissional, o que pode gerar questionamentos tais como: que professor eu sou? Uma dúvida que insurge do "discurso romantizado da academia”. E, o que eu devo fazer aqui, na escola, já que “é outra realidade?”. 
Enfatiza-se, ainda, que, os resultados desta pesquisa convidam-nos para o início de uma ação que contemple reflexões sobre os processos de mudanças em representações que envolvem os papéis dos professores. Coloca-se, aqui, uma possibilidade de (re)fazer caminhos e imagens, a partir do lugar da memória, da experiência e do saber docente, num processo partilhado.

\section{REFERÊNCIAS}

ABREU, Luiz Cláudio Gomes de. Mediação e emoção: A arte na aprendizagem. In: CONGRESSO BRASILEIRO DE COMUNICAÇÃO, 25, Salvador, 2002. Anais... Salvador, 2002. p. 188-188.

AUTHIER-REVUZ, J. Heterogeneidade(s) enunciativa(s). Cadernos de estudos linguísticos, Campinas/SP, UNICAMP - IEL, n. 19, p. 25-42, jul./dez.,1990.

AUTHIER-REVUZ, Jaqueline. Ces mots qui ne vont pas de soi. Boucles réflexives et non-coincidences du dire. 2 vol. Paris: Larousse. 1995.

BAUER, M., Gaskell, G., Allum, N. Qualidade, quantidade e interesses do conhecimento. Evitando confusões. In: BAUER, M.; GASKELL, G. Pesquisa qualitativa com texto, imagem e som: um manual prático. Petrópolis/RJ: Vozes, 2000. p. 17-36.

BRONCKART, J. P. Atividade de linguagem, textos e discursos: por um interacionismo sócio-discursivo. Tradução Anna Rachel Machado. São Paulo: EDUC, 1999.

CHARAUdEAU P. Discurso das mídias. Tradução Ângela S. M. Corrêa. São Paulo: Editora Contexto, 2006.

Charaudeau, P.; MAIngueneau, D. Dicionário de análise do discurso. São Paulo: Contexto, 2004. p. 433.

CHARTIER, R. O mundo como representação. Estudos Avançados, Campinas/SP, Unicamp, 11(5), p. 173$191,1991$.

FERREIRA, M. C. L. Nas trilhas dos discursos: a propósito de leitura, sentido e interpretação. In: ORLANDI, E. (Org.). A leitura e os leitores. Campinas/SP: Pontes, 1998. p. 201-208.

FLICK, Uwe. Uma introdução à pesquisa qualitativa. Porto Alegre: Bookman Editores, 2005.

GALLO, S. Pedagogia libertária: princípios políticos-filosóficos. In: PEY., M. O. (Org.) Educação Libertária: textos de um seminário. Rio de Janeiro: Achiamé; Florianópolis: Movimento, 1996. Disponível em: <http://www.hipernet.ufsc.br/foruns/autonomia/pedago/gallo/princ.htm>. Acessado em: 28 set. 2009.

GROSSMANN, F.; BOCH, F. As representações sociais das práticas de linguagem: como dar conta da complexidade do discurso? In: CORRÊA, M. L. G.; BOCH, F. (Org.). Ensino de Língua: representação e letramento. São Paulo: Mercado de Letras, 2006. p. 11-36.

MARKOVÁ, I. Dialogicidade e representações sociais: as dinâmicas da mente. Tradução de Hélio Magri Filho. Petrópolis/RJ: Vozes, 2006.

MOLINER, Pascal. A estrutura das representações sociais. Trad. Angela Almeida, Carmem Jansen de Cárdenas e Maria Stela de Campos França, com a colaboração de Adriana Giavoni. Do original: P. Moliner. La structure des représentations sociales. In: MOLINER, Pascal. Imagens et representations sociales. Grenoble: PUG, 1996. p. 33-48.

MORIN, Edgar. Os sete saberes necessários à educação do futuro. Trad. Catarina Eleonora F. da Silva e Jeanne Sawaya. Rev. Técnica Edgard de Assis Carvalho. 9. ed. São Paulo: Cortez, 2004.

MOSCOVICI, Serge. Representações sociais: investigações em psicologia social. Tradução de Pedrinho Guareschi. 5. ed. Petrópolis/RJ: Vozes, 2007.

Forum linguistic., Florianópolis, v.11, n.4, p.415-428, out./dez.2014. 
MOSCOVICI, S. A psicanálise, sua imagem e seu público. Tradução de Sonia Fuhrmann. Petrópolis/RJ: Vozes, 2012.

NÓVOA, A. S. A profissão e a prática na formação de professores em Uberaba. In: $4^{\circ}$ Encontro Nacional das Licenciaturas (Enalic) e do $3^{\circ}$ Seminário Nacional do Programa Institucional de Bolsas de Iniciação à Docência (Pibid) - Coordenação de Comunicação Social da Capes. Disponível em: <http://www.capes.gov.br/36noticias/6682-antonio-novoa-fala-sobre-a-profissao-e-a-pratica-na-formacao-de-professores-em-uberaba $>$ Acesso em: 06 dez. 2013.

ORLANDI, E. P. Análise do discurso: princípios e procedimentos. Campinas/SP: Pontes, 1999; 2003, p. 32.

PÊCHEUX, M. Semântica e siscurso. Uma crítica à afirmação do óbvio. 2. ed. Campinas/SP: Ed. da Unicamp, 1988.

ROCHA, Luciana Parente; FIORENTINI, Dario. O desafio de ser e constituir-se professor de matemática durante os primeiros anos de docência. Disponível em: <http://www. anped.org. br/28/textos/qt1971int.rtf $>$. Acesso em: 29 jun. 2012.

SANTAELLA, L. e NÖTH, W. Imagem- cognição, semiótica, mídia. São Paulo: Iluminuras. 1999.

VALA, Jorge. Representações sociais e psicologia social do conhecimento quotidiano. In: VALA, Jorge; MONTEIRO, Maria Benedicta (Edit.). Psicologia social. 7. Ed. Lisboa: Fundação Calouste Gulbenkian. 2007.

WALLON, H. P. H. A evolução psicológica da criança. Lisboa: Edições 70, 2005.

WITtGenstein, L. Investigações filosóficas. Tradução de José Carlos Bruni. São Paulo: Abril Cultural, 1984.

Recebido em 10/02/2015. Aprovado em 30/04/15. 